\title{
Distribution of somatic cell count and udder pathogens in Norwegian dairy goats
}

\author{
M. Smistad, ${ }^{1 *}$ (ㄴ) L. Sølverød, ${ }^{1}$ R. A. Inglingstad, ${ }^{2}$ (1) and O. Østerås ${ }^{2}$ () \\ ${ }^{1}$ TINE Mastitis Laboratory, TINE SA, 6402 Molde, Norway \\ ${ }^{2}$ Department of Research and Development in Dairy Production, TINE SA, 1430 Ås, Norway
}

\section{ABSTRACT}

Compared with dairy cows, goat somatic cell count (SCC) is higher and probably more affected by physiological factors such as parity, stage of lactation, and season. Thus, SCC is believed to be a less precise indicator of intramammary infections in dairy goats, and no consensus exists on SCC thresholds for considering goats as infected. The Norwegian Goat Recording System maintains individual goat production records and results from microbiological analyses of milk samples. In this retrospective observational study, we used recordings over a 10-yr period (2010 to 2020) to describe the association between individual goat SCC and noninfectious factors, as well as intramammary infections. The median SCC in the 1,000,802 milk recordings included in the study was 440,000 cells $/ \mathrm{mL}$, and the mode was 70,000 cells/mL. Somatic cell count increased with parity, days in milk, estrus, pasture season, and intramammary infections. The effect of parity and stage of lactation was significantly higher in infected compared with uninfected goats. Staphylococci dominated as causes of intramammary infections, with Staphylococcus aureus as the udder pathogen associated with highest SCC. The most prevalent non-aureus staphylococci were Staphylococcus warneri, Staphylococcus epidermidis, and Staphylococcus caprae. This study provides guidelines for interpretation of goat SCC at different parities and stages of lactations under Norwegian management conditions. We revealed a considerable variation in SCC associated with physiological factors, indicating that the cutoff for identifying infected goats should be a dynamic threshold adjusted for parity, stage of lactation, and season.

Key words: goat milk, mastitis, non-aureus staphylococci, SCC, Staphylococcus aureus

Received March 31, 2021.

Accepted June 15, 2021.

*Corresponding author: marit.smistad@tine.no

\section{INTRODUCTION}

Mastitis remains the costliest disease in dairy production (Halasa et al., 2007). Elevated SCC has a more diverse spectrum of causes in dairy goats compared with cows. Parity, stage of lactation, estrus, and stress are associated with variation in SCC in goats (Paape et al., 2001; Moroni et al., 2005; Jiménez-Granado et al., 2014). Although various physiological factors have a significant influence on SCC in goats, bacterial IMI are considered the most important cause of prolonged elevated cell counts (Paape et al., 2001; Luengo et al., 2004; Moroni et al., 2005)

In dairy goats, mastitis is predominantly subclinical, and staphylococci cause the majority of IMI (White and Hinckley, 1999; Bergonier et al., 2003). Non-aureus staphylococci (NAS) are the most prevalent findings of subclinical IMI, whereas Staphylococcus aureus (Staph. aureus) is the most common major pathogen in dairy goats (Deinhofer and Pernthaner, 1995; Koop et al., 2011). The distribution of udder pathogens in the Norwegian goat population has not been reported previously.

Several studies have investigated the distribution of SCC in goats, as well as factors associated with variation, but most studies are performed in a low number of herds (e.g., Leitner et al., 2004; Luengo et al., 2004; Persson and Olofsson, 2011). The influence of physiological and pathological factors on goat SCC is still largely unknown, and the SCC threshold above which goats should be considered infected is yet to be defined.

The Norwegian goat population has been through fundamental changes the last decade. Lentiviral caprine arthritis encephalitis infections, caseous lymphadenitis, and paratuberculosis were eradicated from the dairy goat population through the Healthier Goats eradication program from 2001 to 2015 (Nagel-Alne et al., 2014). Furthermore, the prevalence of a genetic mutation associated with poor coagulation properties and high levels of free fatty acids has been reduced in the goat population through a targeted breeding program 
(Devold et al., 2011; Ådnøy, 2014; Skeie et al., 2014). These changes have led to substantial improvement of goat milk quality. However, further improvements are possible by reducing the incidence of IMI.

Norwegian farmers have a long tradition of milk recording, for both dairy cattle and dairy goats. A minimum of 3 milk recordings (individual goat composite samples measuring fat percentage, protein percentage, lactose percentage, SCC, free fatty acids, and milk yield) per year are required for members of the Norwegian Goat Recording System (NGRS), but 5 yearly test days are recommended to monitor udder health. In the period from 2010 to 2020,93 to $94 \%$ of goat farmers were reporting to NGRS (TINE, 2020).

The Norwegian dairy cooperative TINE SA operates an accredited veterinary diagnostic laboratory service (TINE Mastitis Laboratory, Molde, Norway). Farmers are encouraged to submit milk samples for bacteriological investigation in case of clinical mastitis as well as before drying off goats with subclinical mastitis. In addition, in herds experiencing high bulk milk total bacterial count or SCC, milk samples are submitted from goats that are suspected of having an IMI and may be likely contributors to the bulk milk total bacterial count or SCC. Results from the bacterial culture are stored in a central database and combined with the goat's history of SCC in decision-support tools. This gives the opportunity to analyze the distribution of SCC according to parity, DIM, and season, combined with bacteriological results of analyses from an accredited laboratory.

The primary aim of this study was to describe the association between goat SCC and physiological and pathological factors. Secondarily, the distribution of udder pathogens in the Norwegian dairy goat population is presented.

\section{MATERIALS AND METHODS}

\section{Study Population}

The population in this retrospective observational study was all dairy goats from farms that were members of the NGRS during the period 2010 to 2020 . The number of farms has decreased from 312 to 241 during the same period, and the average herd size for members of NGRS has increased from 92.6 to 128.1 goats. The dairy goats are held indoors during the winter season and kept on pasture (mainly mountain pasture) during the summer months. In 2019, $30 \%$ of Norwegian goat milk was produced on pasture (TINE, 2020). The pasture season starts between May and June and ends in September or October, depending on the local climate. The mean number of pasturing days is $135 \mathrm{~d}$ (4.5 mo).
Most Norwegian dairy goats have a dry period of 2 to 4 mo. Total dry goat therapy is not practiced in Norway, and goats infected with major udder pathogens have usually been culled. However, since 2010, interest in selective dry goat therapy has been increasing. The majority of the herds $(76.5 \%)$ have concentrated kidding during the 3 mo of January, February, and March. The main breed is the Norwegian dairy goat.

\section{SCC Data}

Individual goat milk SCC data were extracted from the NGRS database, together with parturition date and parity $(1,2,3,4, \geq 5)$. The DIM was calculated as the difference between test day and parturition date. All samples taken after 590 DIM were excluded. In total, $1,000,802$ milk recordings were included.

A subset of observations was used to evaluate associations between SCC and bacteriological diagnosis. Samples from goats with a bacteriological sample within $15 \mathrm{~d}$ before or after a milk recording were included. Recordings after 330 DIM were excluded. In total, 20,201 goat-level bacteriological results analyzed at the TINE Mastitis Laboratory between 2010 and 2020, from goats with an SCC milk recording within 15 $\mathrm{d}$, were included in the analyses.

A Fossomatic FC (Foss Electric) was used to analyze SCC until 2016; thereafter a Bentley FTS (Bentley Instrument Inc.) was used. In NGRS, SCC values above 10 million cells $/ \mathrm{mL}$ are truncated to the number 9,989,000 cells/mL.

\section{Microbiological Data}

Microbiological diagnoses of udder half milk samples analyzed at TINE Mastitis Laboratory between January 2010 and December 2020 were retrieved from the NGRS. Udder half milk samples were taken by the farmer or veterinarian using aseptic technique, and the most common reason for submitting samples for bacteriological culture is suspicion of subclinical or clinical mastitis. Upon arrival at the laboratory, bacteriological culturing was performed according to standard procedures (Hogan et al., 1999). Briefly, $0.01 \mathrm{~mL}$ of milk from each half was spread on cattle blood agar plates with esculin and incubated at $37^{\circ} \mathrm{C}$. Plates were read at $24 \mathrm{~h}$ and $48 \mathrm{~h}$. Staphylococcus aureus was identified by typical colony morphology and the presence of $\alpha \beta$-hemolysis. Prior to 2016, species identification of staphylococci was performed by coagulase test. From 2016, species identification was performed with MALDI-TOF MS (Microflex LT system, Bruker Daltonics). The NAS species-level reports were implemented in the NGRS from 2019, where isolates with a MALDI-TOF 
score $\geq 2$ for a given species were considered adequate to be reported at species level. Milk samples yielding more than 2 different colony types were classified as contaminated.

\section{Statistics}

Distribution of $S C C$. The data were organized and analyzed using SAS software v. 9.4 (SAS Institute Inc.). First, median and mode SCC values were described for each parity. Thereafter, associations between the natural logarithm of SCC (ln SCC) and parity, estrus, DIM, DIM $\times$ DIM, and ln of DIM, as well as month of the year, were assessed using generalized linear models (Proc GLM), and Proc Mixed was used when random herd effect was included. Due to the strong seasonality in the Norwegian goat production, characterized by breeding season in early autumn and kidding season early in the following year, the collinearity between calendar month and (a) estrus and (b) DIM was strong $(\mathrm{r}>0.7)$. Therefore, separate models were built. (1) The first was a mixed model with $\ln$ SCC as dependent variable, and parity and DIM as independent variables, with herd included as a random effect. (2) For the association between ln SCC and month of year, separate models were made for each $30-\mathrm{d}$ period of DIM. The first $30 \mathrm{~d}$ were split into 2 parts: 0 to $14 \mathrm{~d}$ and 15 to 30 d. The mean of ln SCC with standard error (SE) for each month of the year was estimated for each lactation stage period within each parity group. Only months with more than 100 observations per lactation stage were presented. The periods 15 to 30 DIM, 91 to 120 DIM, and 191 to 210 DIM were selected to represent early, mid-, and late lactation, respectively. As estrus occurs during late summer in the majority of the herds, milk recordings close to estrus (as described subsequently) were excluded when evaluating the effect of season. (3) For the effect of estrus on SCC, milk recordings in the period between $15 \mathrm{~d}$ before to $15 \mathrm{~d}$ after conception were used, with the estimated day of conception calculated as the parturition date minus 150 d. A generalized linear model was made for each parity, where ln SCC was the dependent variable and days from estimated estrus was the independent variable. Days from conception was used as a class variable. Mean ln SCC and SE were estimated for each day and parity.

Model estimates were presented as the geometric mean SCC (which corresponds to the exponent of mean ln SCC), with the $95 \%$ confidence interval for the mean calculated as the exponent of the mean $\ln \mathrm{SCC} \pm(1.96$ $\times \mathrm{SE})$.

Association Between SCC and Bacteriology. Distributions of goat-level bacterial diagnoses were described at different parities with DIM and SCC (median and interquartile range). Streptococcus agalactiae, Streptococcus dysgalactiae, and Streptococcus uberis were classified as Streptococcus spp. Goats with NAS infection in one udder half and Staph. aureus or streptococci on the contralateral side were classified according to the Staph. aureus or streptococcal infection.

The association between bacteriological findings and SCC was assessed with separate generalized linear models for goats with known bacteriological status on both udder halves for each of the following IMI categories: culture negative (no growth, both halves), NAS (one half), and Staph. aureus (one half). Only goats with no growth on the contralateral udder half were included as NAS or Staph. aureus in the models. The ln SCC was the dependent variable, and IMI category, DIM, DIM $\times$ DIM, and ln of DIM were independent variables. Separate models were made for each parity group. Finally, the models were run as mixed models with herd as random effect.

\section{RESULTS}

\section{Distribution of Goat SCC}

A total of 1,000,802 SCC results from milk recordings were included, and the distribution of SCC per milliliter is presented in Figure 1. The results were obtained from 114,770 goats from 385 herds. The arithmetic mean for all recordings was 988,000 cells $/ \mathrm{mL}$, with a standard distribution of $1,539,000$ cells $/ \mathrm{mL}$. The geometric mean was 443,000 cells/mL, and the mode was 70,000 cells/ $\mathrm{mL}$. The distribution of samples, with the median and mode SCC for each parity, is presented in Table 1.

A 2-peak distribution was evident in the ln-transformed SCC, with a separation between the peaks at ln 5.5 , corresponding to SCC at 245,000 cells/mL (Figure 2 ). This distribution warranted further investigation. By dividing the recordings into "low SCC" (SCC $\leq 245,000$ cells $/ \mathrm{mL}$ ) or "high SCC" ( $\mathrm{SCC}>245,000$ cells $/ \mathrm{mL}$ ), this 2-peak distribution was only partly explained by parity: $45.2 \%$ were at low level in first parity, $34.8 \%$ in second parity, $29.0 \%$ in third parity, $25.4 \%$ in fourth parity, and $20.8 \%$ in older does. With respect to year, the low class increased from $26 \%$ in 2010 to $38 \%$ in 2015 , and thereafter remained relatively stable, with $33 \%$ at the end of the study period in 2020 . We found a difference of 42 DIM between the 2 groups, with a mean of 149 DIM [standard deviation (SD) 76] for the high group and 106 DIM (SD 72) for the low group.

The cluster effect of herd in the mixed model using all SCC data was estimated to $9.5 \%$. The association between the stage of lactation and SCC (geometric mean) increased with parity (Figure 3 ). 
Table 1. Descriptive statistics of mode and median SCC $(\times 1,000 \text { cells } / \mathrm{mL})^{1}$ at different parities from goat milk recordings in the Norwegian Goat Recording System between 2010 and 2020

\begin{tabular}{lccccr}
\hline Parity & $\mathrm{n}$ & Mode SCC & Median SCC & Q1 & Q3 \\
\hline 1 & 298,901 & 70 & 290 & 120 & 740 \\
2 & 241,858 & 70 & 420 & 170 & 1,030 \\
3 & 177,560 & 70 & 510 & 210 & 1,230 \\
4 & 122,569 & 110 & 570 & 240 & 1,330 \\
$>4$ & 159,914 & 110 & 660 & 290 & 1,470 \\
All parities & $1,000,802$ & 70 & 440 & 170 & 1,090 \\
\hline${ }^{1}$ Q1 and Q3 $=$ lower and upper quartile, respectively. & & &
\end{tabular}

The association of season (month of the year) on SCC for early, mid-, and late lactation is presented in Figure 4. An association between estrus and SCC was present in all parities (Figure 5). The mean increase of SCC at breeding (all parities) was 315,000 cells $/ \mathrm{mL}$ from $5 \mathrm{~d}$ before to $2 \mathrm{~d}$ after estimated conception. The increase in SCC related to estrus was strongest in fourth parity $(422,000$ cells $/ \mathrm{mL})$ and least prominent in second parity $(241,000$ cells $/ \mathrm{mL})$.

\section{Association Between SCC and Bacteriological Results}

Altogether, 20,201 milk sample culture results came from goats that had a milk recording within $15 \mathrm{~d}$ before or after the date of sampling. The samples were obtained from 10,338 goats in 170 herds. Of these, 6,256 goats $(61 \%)$ had only 1 bacteriological result linked to a milk recording, whereas 2,267 (22\%), 1,063 (10\%), and $752(7 \%)$ goats had 2,3 , or more than 3 bacteriological results linked to a milk recording, respectively. The mean number of samples per herd in the 10-yr period was 461 (range 2 to 809). The most common stages of lactation to submit a milk sample for bacteriological culture were from 19 to 85 DIM and from 200 to 270 DIM, with $39 \%$ and $21 \%$ of the samples, respectively. For 11,325 of the samples (56\%), the goat was sampled on both udder halves, and the remaining goats were sampled on the symptomatic udder half only.

The distribution of goat-level bacteriological diagnoses at different parities is presented in Table 2. Only 4 goats from 3 herds had Strep. agalactiae infection.

The geometric mean SCC adjusted for parity and DIM for goats with no bacteriological sample was 522,000 (95\% CI: 503,000-541,000) cells/mL, whereas the corresponding SCC for goats with milk sample were

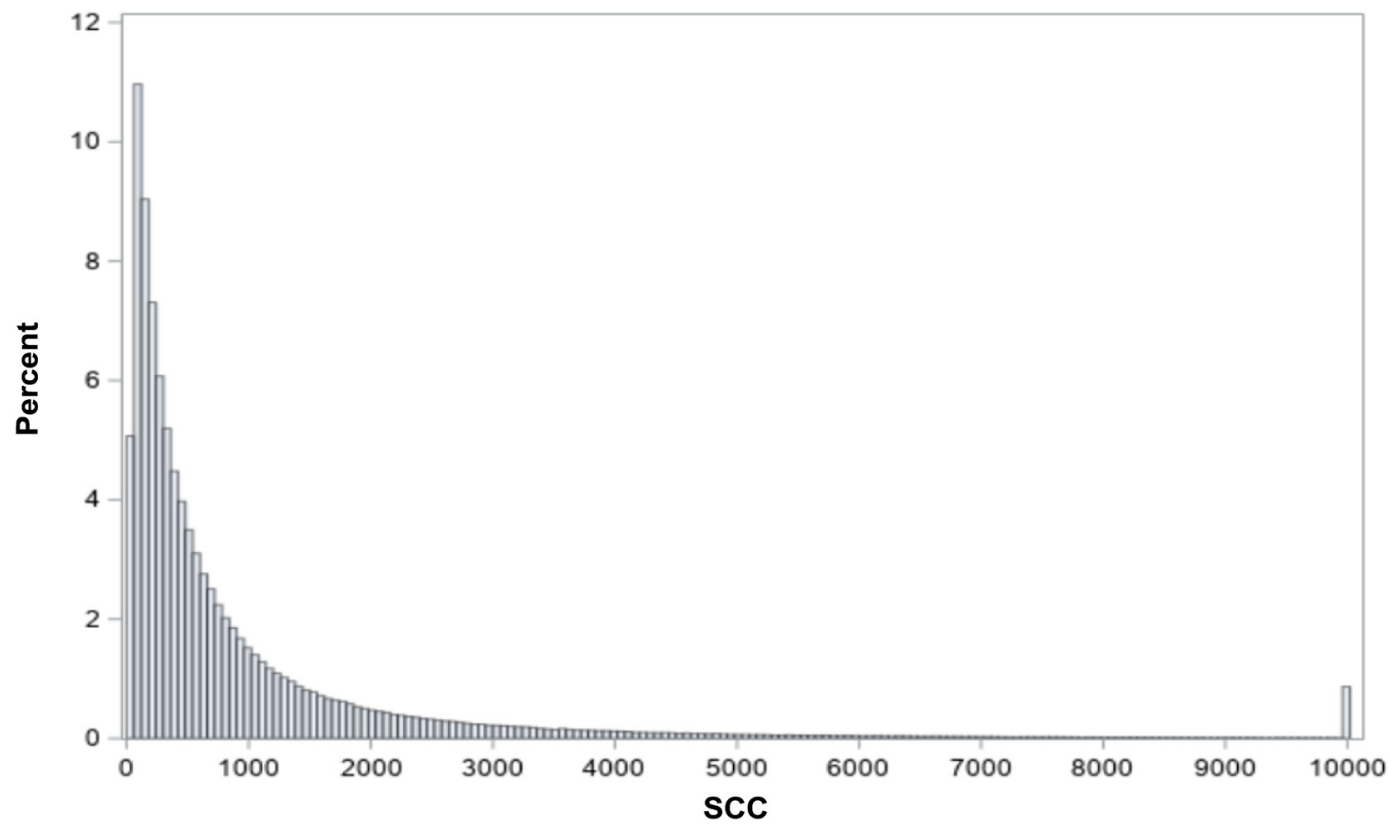

Figure 1. Distribution of SCC $(\times 1,000$ cells $/ \mathrm{mL})$ in goat milk from 1,000,802 milk recordings in the Norwegian Goat Recording System from 2010 to 2020 . The SCC values are truncated above $10,000,000$ cells $/ \mathrm{mL}$. 
780,000 (95\% CI: 743,000-818,000) and 794,000 (95\% CI: $762,000-827,000)$ cells $/ \mathrm{mL}$ for culture-negative and culture-positive goats (any isolate), respectively.

The geometric mean SCC at different parities and 3 IMI categories [(1) negative/negative, (2) Staph. aureus/negative, and (3) NAS/negative], are presented in Table 3. In total, 9,372 samples from 8,657 goats in 147 herds were included in these models. The SCC (geometric means) estimated from the mixed models for associations between ln SCC and the same 3 IMI categories and DIM are presented in Figure 6 for all parities.

The herd random effect for ln SCC in the complete data set $(\mathrm{n}=1,000,802)$ was $9.5 \%$. The herd effect for $\ln$ SCC restricted to the material with bacteriological samples $(\mathrm{n}=20,201)$ was $8.7 \%$. In the model with Staph. aureus as independent variable, the herd random effect was $18.8 \%$, and in the model with NAS as independent variable, the random effect at herd level was $20.9 \%$.

\section{DISCUSSION}

This study describes individual goat SCC in more than one million milk recordings in Norwegian dairy goats over a 10-yr period. This is, to our knowledge, the first large-scale descriptive study of goat SCC. The associations between SCC and parity, DIM, month of year, breeding, and bacteriological findings were explored.

The distribution of all SCC showed a typical lognormal distribution. The long tail to the right is explained by the exponential cascade reaction of the SCC response and is the same pattern as for cow milk SCC (IDF, 1997). This study confirms the higher mean and mode in goat milk compared with cow milk, which has also been reported previously (Paape et al., 2001; Jiménez-Granado et al., 2014). The extremely high SCC recordings contributing to the right-skewed distribution increase the arithmetic mean to be substantially higher than the representative SCC value for the population. Because our aim was to describe the physiological normal SCC of goats, we used the median and mode SCC for descriptive statistics. For model estimates, we back-transformed ln SCC to numeric values (in cells per milliliter) by using the exponent of ln SCC, which is the geometric mean SCC. This was done to provide guidelines for direct interpretation of goat SCC in total number of cells per milliliter. The distribution showed that the geometric mean of all recordings in the study $(443,000$ cells $/ \mathrm{mL})$ was close to the median value of the population $(440,000$ cells $/ \mathrm{mL})$ and, thus, is a more representative measure of the SCC in goats than the arithmetic mean $(988,000$ cells $/ \mathrm{mL})$.

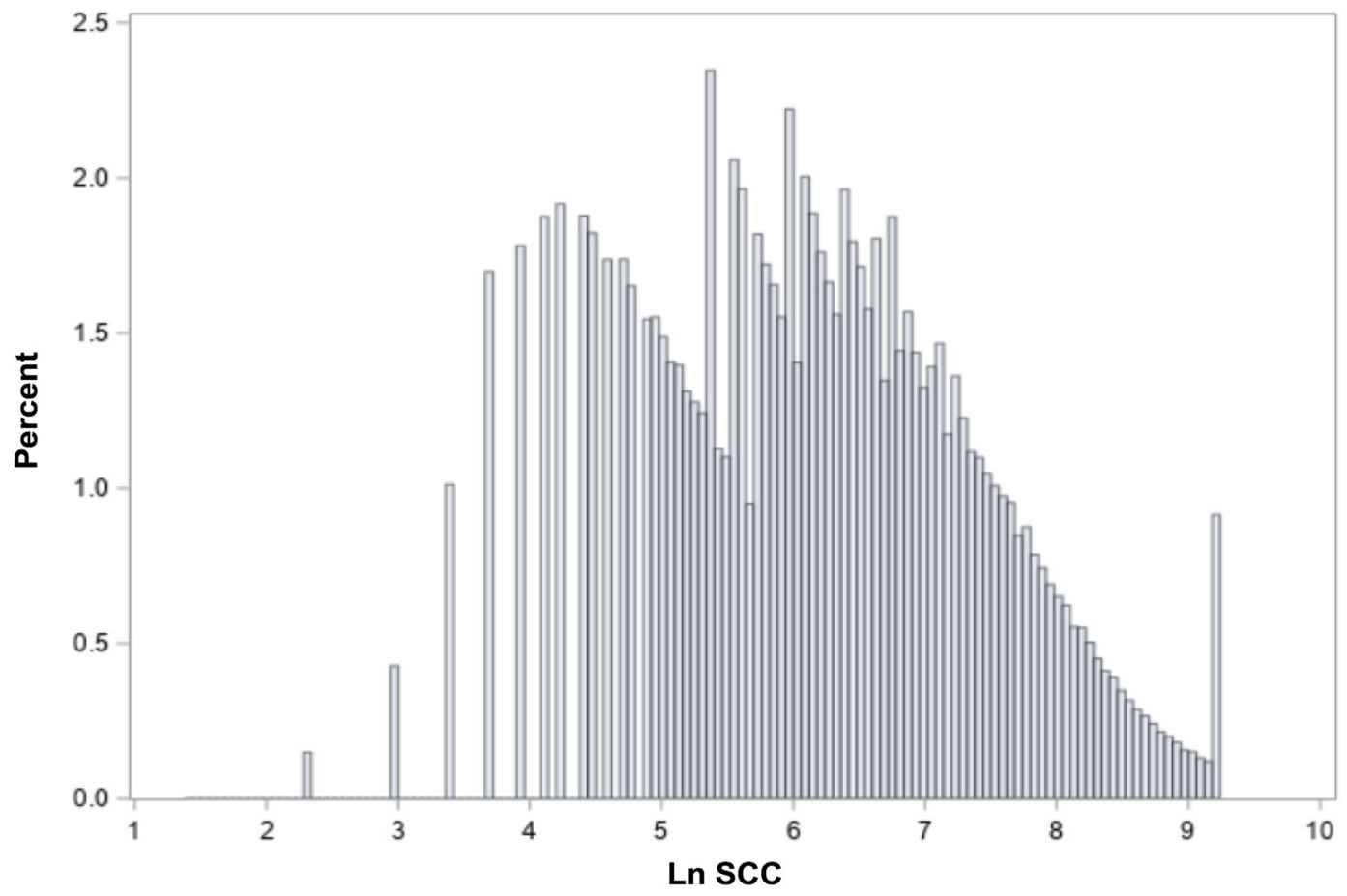

Figure 2. Distribution of natural logarithm (ln) of SCC in 1,000,802 milk recordings from the Norwegian Goat Recording System from 2010 to 2020. The SCC values are truncated above $9,989,000$ cells $/ \mathrm{mL}$, corresponding to recordings with $\ln$ SCC of 9.2. 


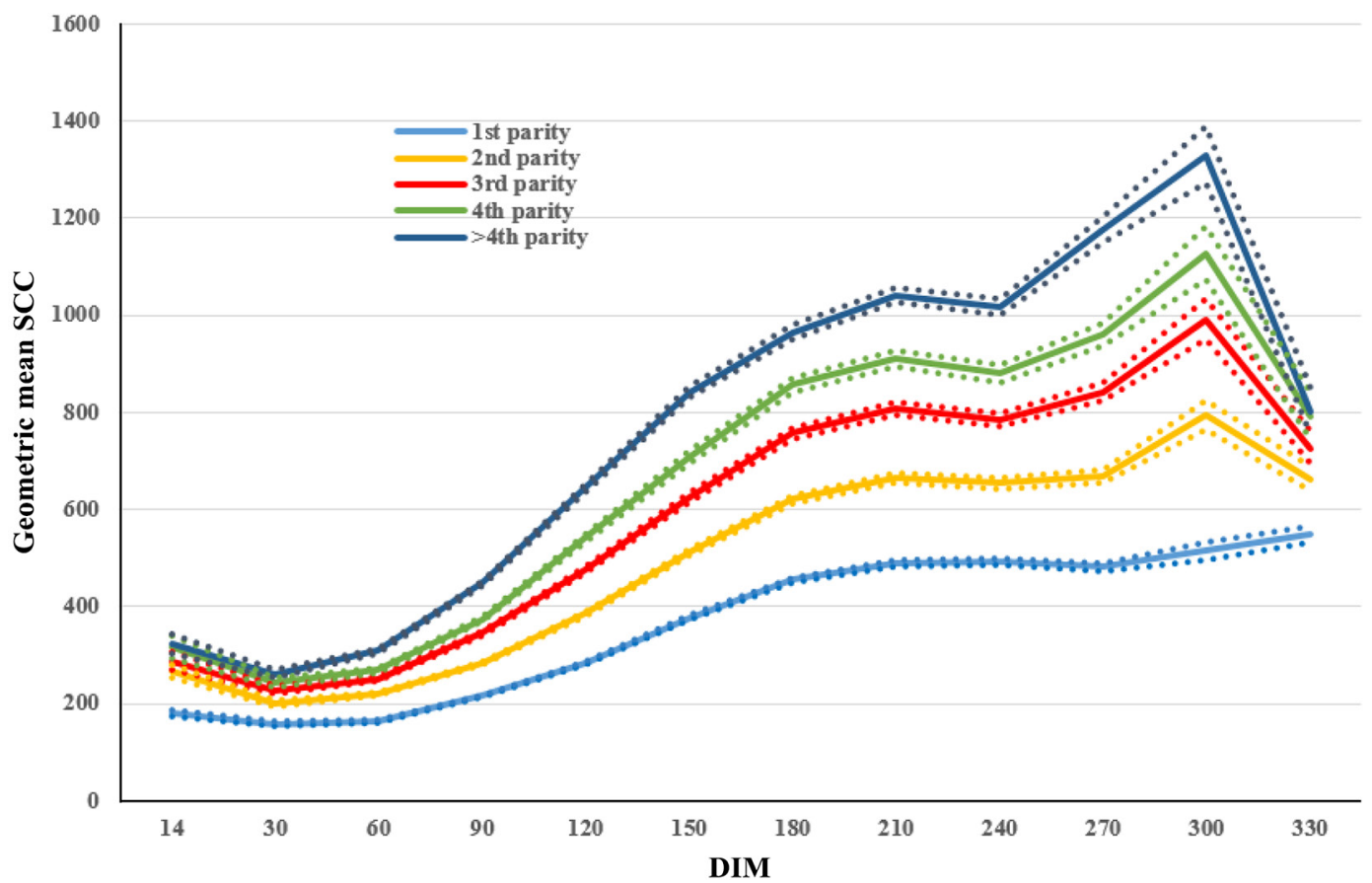

Figure 3. Goat milk geometric mean SCC $(\times 1,000$ cells $/ \mathrm{mL})$ for each parity, with $95 \%$ CI (dotted lines) at different stages of lactation, from $1,000,802$ milk recordings in the Norwegian Goat Recording System from 2010 to 2020.

Interestingly, a peculiar 2-peak distribution in the log-transformed SCC was revealed (Figure 2). The separation between these 2 peaks at $\ln 5.5$ or 245,000 cells/ $\mathrm{mL}$ could be an indication of a cutoff of pathologic or physiological impact. When exploring the difference between recordings above and below this limit, we found that the proportion of lower SCC increased from 2010 to 2015. This could be an effect of the Healthier Goats project, under which caprine arthritis encephalitis was eradicated from the Norwegian goat population during this period. This phenomenon warrants further investigation.

The positive association between SCC and parity in goats has been described in several studies (Paape et al., 2001; Bergonier et al., 2003; Leitner et al., 2007) and is also seen in dairy cows (de Haas et al., 2004; Reksen et al., 2008; Taponen et al., 2017). This was confirmed in this study with a significant increase for each parity up to parity 5 . The reasons for this effect are not completely understood. Older goats may have had extended exposure to udder pathogens, and goats with a previous IMI may have chronic changes in the udder parenchyma (Leitner et al., 2007; Jiménez-Granado et al., 2014). We identified a higher prevalence of Staph. aureus infections in primiparous compared with multiparous goats in this study, whereas the prevalence of NAS infections was higher for multiparous goats (Table 2). Although the history of exposure to udder pathogens was unknown, we consider it likely that this partly explains the parity effect in goats.

The difference between parities was not very prominent before 60 DIM but increased thereafter (Figure 3). The effect of lactation stage presented here was confounded by the effect of the pasture season, which commonly starts between 60 and 120 DIM in Norwegian goat flocks. Furthermore, the infection status for the majority of observations was unknown. The effect of the lactation stage is evident in goats, and some authors have stated that the physiological high SCC of goats at the end of lactation make SCC an unsuitable tool for distinguishing infected from noninfected goats (Moroni et al., 2005). The current study confirms the marked increase of SCC in late lactation; however, if adjusted for parity, the SCC in late lactation is significantly higher in infected goats compared with culture-negative goats (Figure 6). Although a stronger effect of DIM was seen in $S$. aureus-infected goats, the culture-negative goats also reached a geometric mean of $>1,000,000$ cells $/ \mathrm{mL}$ in mid and late lactation. This cutoff has been commonly used for suspicion of IMI in Norway. Based on the results of this study, this threshold for identifying infected goats in late lactation is probably too high for younger goats (goats in first and second parity) and too low for goats in higher parities. The increase of SCC toward the end of the lactation is usually explained by a concentration effect (Paape et al., 2001). However, 
a 5 -fold increase in SCC from 30 to 200 DIM is not related to the same decrease in production. Leitner et al. (2007) detected a significant increase in SCC in pregnant does and a net accumulation of IMI in the herd during lactation. We found that NAS infections and infections in both udder halves were more common toward the end of lactation, which could indicate that an accumulation of persistent infections partly explains the effect of DIM.

A drop in SCC for all parities after 300 DIM (Figure 3) was revealed. The reasons for this drop could not be identified. One possible explanation is selection of animals toward the end of lactation. Goats with IMI, high SCC, or low production will be dried off or culled before the next the lactation, and goats with satisfactory yield and SCC are kept longer in production to fill the milk quota. It could also be a consequence of the management system, as most of the goats are kept indoors at this stage of lactation, or errors in the registrations of kidding for the subsequent parity.

Because most Norwegian goat farmers have kidding in the period between December and February, it was not possible to evaluate the association of DIM and season on SCC in the same model, due to collinearity. This problem was solved by making separate models for different $30-\mathrm{d}$ periods in lactation. In this way it was possible to evaluate the association between season and SCC for each parity while controlling for lactation stage. The results illustrate an effect of the pasture season on SCC, in particular in July and August. The effect was strongest for goats in late lactation. Whether the increase in SCC during the late pasture season was due to increased movement, heat stress, or increased infection pressure could not be assessed with the data available in this study.

A transient increase in SCC was seen at the time of estrus. This period of increase lasted mainly from $5 \mathrm{~d}$ before to $10 \mathrm{~d}$ after breeding. The SCC increased more in multiparous goats compared with primiparous goats. Interestingly, the peak of SCC was $2 \mathrm{~d}$ after estimated conception. The reason for this delay is unknown, but it could indicate that the estimate of 150-d pregnancy was not exact. The peak was more distinct in young goats than in older goats, which could indicate a larger variation in pregnancy length in older goats.

Staphylococcal IMI accounted for $87 \%$ of the bacteriological positive samples. Our most common findings were NAS and Staph. aureus, with 59 and $28 \%$ of the culture-positive samples, respectively (Table 2). The proportion of samples in total was higher for Staph. aureus $(15 \%)$ and lower for NAS $(30 \%)$ than reported in other studies (White and Hinckley, 1999; Bergonier
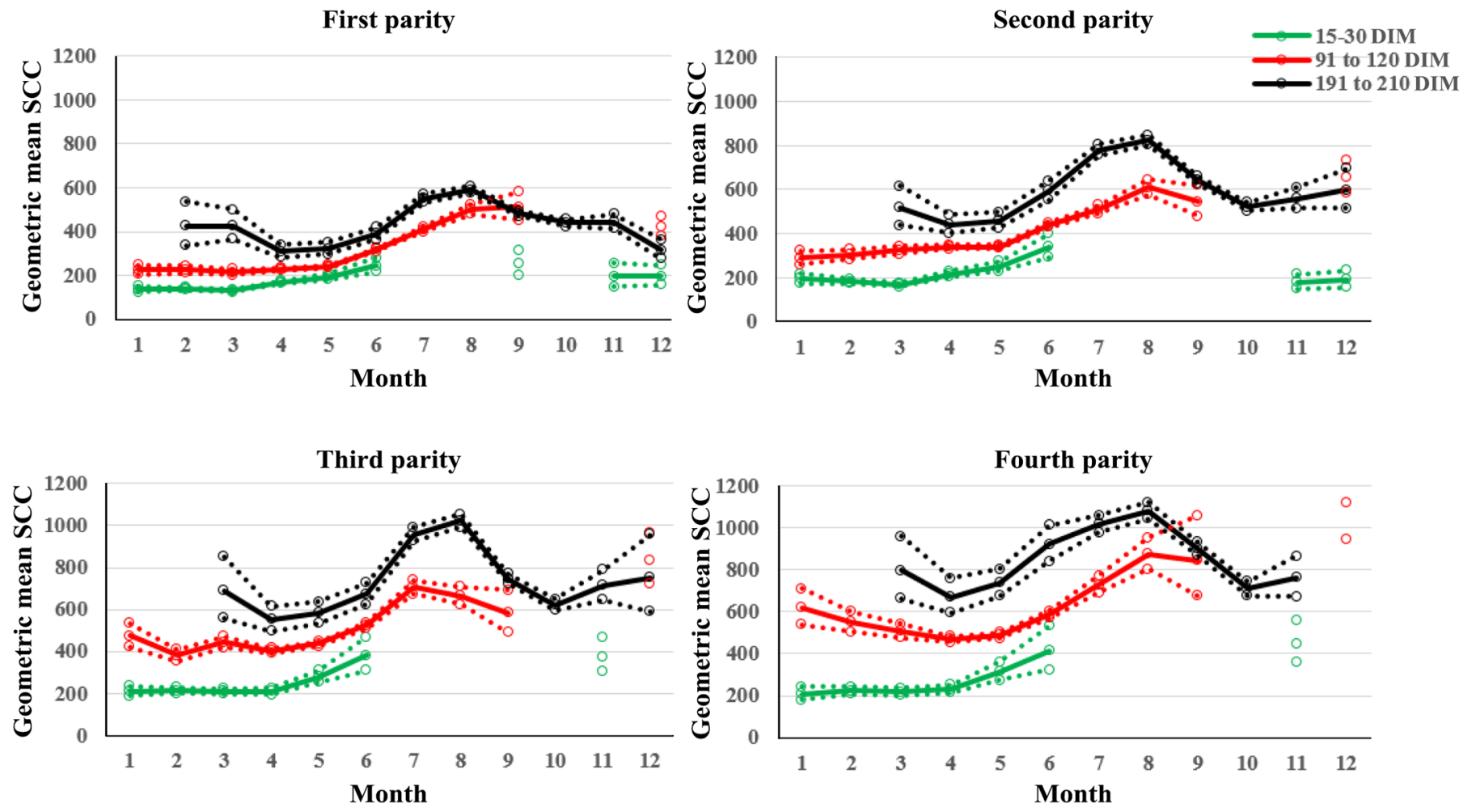

Figure 4. Goat milk geometric mean SCC $(\times 1,000$ cells $/ \mathrm{mL})$ and $95 \%$ CI (dotted lines) in each month of the year for recordings in early (15-30 DIM), mid (91-120 DIM), and late (191-210 DIM) lactation. Only months with more than 100 samples are presented. 
Table 2. Distribution (number of observations; IQR = interquartile range) of bacteriological diagnoses with respect to parity, DIM, and SCC $(\times 1,000$ cells/mL) of 20,201 milk samples from 10,338 goats in 170 herds

\begin{tabular}{|c|c|c|c|c|c|c|c|c|}
\hline Bacteriological diagnosis & Total & \multicolumn{5}{|c|}{ Parity } & $\begin{array}{l}\text { Median DIM } \\
\quad(\mathrm{IQR})\end{array}$ & $\begin{array}{l}\text { Median SCC } \\
\quad(\mathrm{IQR})\end{array}$ \\
\hline Staph. aureus $(2)^{2}$ & 219 & 75 & 57 & 44 & 26 & 17 & $176(78-225)$ & $2,990(1,020-5,380)$ \\
\hline NAS $(1)^{1}$ & 4,603 & 1,075 & 1,254 & 981 & 626 & 667 & $102(53-219)$ & $750(270-1,710)$ \\
\hline NAS $(2)^{2}$ & 1,051 & 326 & 334 & 178 & 114 & 99 & $206(73-241)$ & $1,420(760-2,430)$ \\
\hline Staphylococcus caprae & 113 & 24 & 26 & 21 & 20 & 22 & $77(69-218)$ & $290(130-1,120)$ \\
\hline Streptococci ${ }^{3}$ & 59 & 15 & 17 & 10 & 8 & 9 & $80(33-164)$ & $2,150(580-5,310)$ \\
\hline Other bacteria $^{4}$ & 954 & 291 & 255 & 216 & 101 & 91 & $85(34-173)$ & $555(140-1,730)$ \\
\hline Contaminated & 323 & 46 & 80 & 98 & 57 & 42 & $140(99-197)$ & $890(260-1,760)$ \\
\hline Total & 20,201 & 5,974 & 5,271 & 3,960 & 2,390 & 2,606 & $112(55-223)$ & $710(180-1,960)$ \\
\hline
\end{tabular}

${ }^{1}$ Infected in one udder half.

${ }^{2}$ Infected in both udder halves.

${ }^{3}$ Streptococci: Streptococcus dysgalactiae (35), Streptococcus uberis (24), Streptococcus agalactiae (4).

${ }^{4}$ Other bacteria cultured: $\alpha$-streptococci other than Strep. dysgalactiae and Strep. uberis (196), Bacillus (120), Corynebacterium (100), enterococci (83), Escherichia coli (24), Trueperella pyogenes (16), other bacteria (415).

et al., 2003). One explanation for this is that we used samples submitted to routine diagnostics. Milk samples are most often submitted from goats selected based on a high SCC test day result or California Mastitis Test results. Therefore, the bacteriology data presented in this study were overrepresented by samples from goats
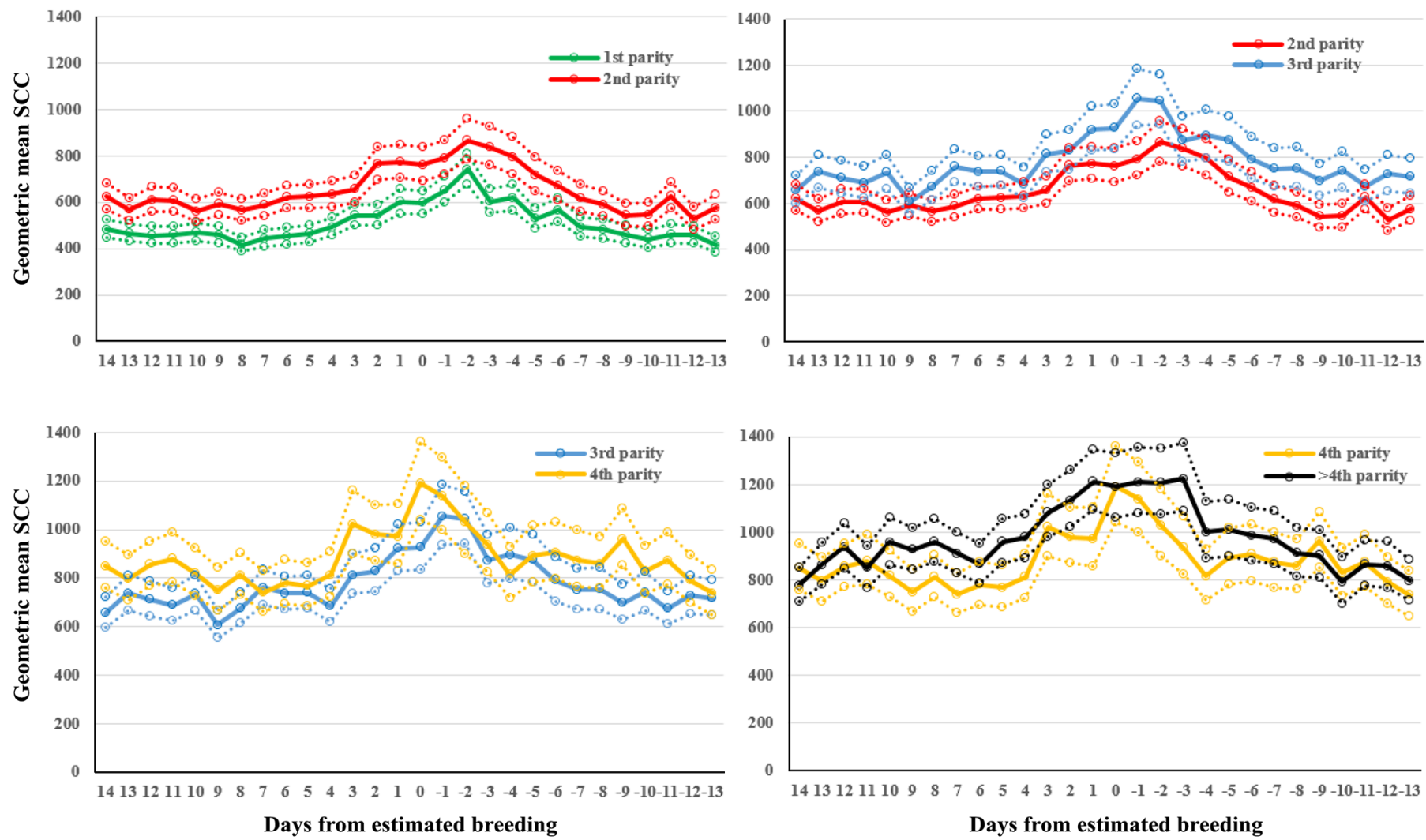

Figure 5. Goat milk geometric mean SCC and 95\% CI (dotted lines) from $14 \mathrm{~d}$ before to $14 \mathrm{~d}$ after estrus. Conception day is estimated as $150 \mathrm{~d}$ before kidding. The x-axis shows days from estimated breeding; negative values are milk samples taken after the estimated breeding date, and positive values were taken before. The y-axis shows geometric mean SCC $(\times 1,000$ cells $/ \mathrm{mL})$. 
with subclinical mastitis. The role of Staph. aureus as an important udder pathogen in goats is well known, and the main goal of udder health programs in Norwegian dairy goat herds has been to reduce the incidence of Staph. aureus IMI. Despite this, the proportion of Staph. aureus infections remained relatively stable through the study period (results not shown).

The importance of NAS-infected goat as contributors to goat bulk milk SCC is more unclear. Bagnicka et al. (2011) detected similar changes in SCC and the same elevation in percentage of different subpopulations of leukocytes in NAS-infected goat as in goats infected with major pathogens. As a group, NAS-infected goats had an overlap in SCC confidence intervals with culturenegative goats in the current study. However, because NAS are a heterogeneous group of bacterial species, effects of some more pathogenic species can be elucidated by species with less effect on udder health (Koop et al., 2012; Bernier Gosselin et al., 2020). Species-level studies of NAS in goats have only been performed in a low number of herds.

Non-aureus staphylococci were reported at species level in the 2 last years of the study (2019 and 2020). Staphylococcus warneri was the most common NAS isolated, and this species has only been sporadically detected in other studies (Contreras et al., 1995; Deinhofer

Table 3. Geometric mean ${ }^{1}(95 \%$ CI $)$ for goat SCC $(\times 1,000$ cells $/ \mathrm{mL})$ in different parities according to bacteriological identification in 9,372 milk samples from 8,657 goats in 147 herds

\begin{tabular}{|c|c|c|c|}
\hline $\begin{array}{l}\text { Parity and } \\
\text { infection status }\end{array}$ & $\mathrm{n}$ & $\begin{array}{l}\text { Geometric } \\
\text { mean SCC }\end{array}$ & $95 \%$ CI \\
\hline \multicolumn{4}{|l|}{1} \\
\hline Negative & 1,293 & 391 & $373-410$ \\
\hline NAS & 768 & 831 & $730-946$ \\
\hline Staph. aureus & 575 & 1,092 & $934-1,276$ \\
\hline \multicolumn{4}{|l|}{2} \\
\hline Negative & 1,363 & 559 & $532-587$ \\
\hline NAS & 719 & 1,023 & $900-1,162$ \\
\hline Staph. aureus & 387 & 1,315 & $1,107-1,561$ \\
\hline \multicolumn{4}{|l|}{3} \\
\hline Negative & 1,139 & 654 & 621-690 \\
\hline NAS & 520 & 1,208 & $1,054-1,388$ \\
\hline Staph. aureus & 266 & 1,517 & $1,249-1,842$ \\
\hline \multicolumn{4}{|l|}{4} \\
\hline Negative & 737 & 731 & $685-781$ \\
\hline NAS & 344 & 1,193 & $1,025-1,388$ \\
\hline Staph. aureus & 139 & 1,599 & $1,248-2,047$ \\
\hline \multicolumn{4}{|l|}{$>4$} \\
\hline Negative & 695 & 764 & $720-810$ \\
\hline NAS & 281 & 1,433 & $1,219-1,685$ \\
\hline Staph. aureus & 146 & 1,934 & $1,515-2,469$ \\
\hline Total & 9,372 & & \\
\hline
\end{tabular}

${ }^{1}$ Least squares means of natural logarithm of SCC is adjusted for DIM and herd random effect, and back-transformed to SCC.

${ }^{2}$ Infection status: negative $=$ no growth in both halves; NAS $=$ nonaureus staphylococci in one half, no growth in the contralateral half; Staph. aureus $=$ Staphylococcus aureus in one half, no growth in the contralateral half. and Pernthaner, 1995; Koop et al., 2012). The Staph. warneri infections were associated with a noteworthy increase in SCC, with a median SCC comparable to that of goats infected with Staph. aureus (Table 2). The prevalence of Staph. warneri infections increased toward the end of lactation (median DIM: 220). The recent introduction of MALDI-TOF to routine diagnostics in several countries will increase knowledge about NAS infections in the future, and the results from the first years of diagnosing NAS at species level in Norway underline the importance of species-specific diagnostics of these species.

One limitation of this study was that, for the majority of recordings, infection status was unknown. Furthermore, DIM and season were highly correlated, which made us unable to set an operational cutoff accounting for all the conditions associated with variation of SCC. Instead, we attempted to describe the conditions separately (e.g., the effect of season), and, with these confounding effects in mind, our described levels of SCC at different parities and stages of lactation (Figure 3) can give an indication of what "normal" goat SCC is. Because bacteriological culture has a high specificity, the model estimates presented in Figure 6 give a good indication of the level of SCC for goats with IMI caused by Staph. aureus and NAS. The curve for the culture-negative goats, however, is not truly representative of healthy goats, because the goats were selected for sampling for a reason (most commonly subclinical mastitis). Bacteriological culture is known to have low sensitivity, and some of the culture-negative samples probably came from goats that had cleared infections, intermittent shedding of bacteria, or nonculturable bacteria.

Based on this large-scale description of goat milk SCC recordings, the fixed threshold of 1,000,000 cells/ $\mathrm{mL}$ used until now in the Norwegian goat advisory service should be replaced with dynamic thresholds. Such thresholds (i.e., adjusted for parity and stage of lactation) will always be a very rough approximation, as the SCC distributions of infected and uninfected goats may overlap. Furthermore, the farm-level variance was considerable. The herd cluster effect for variation of SCC was $9 \%$ in the total material and 18 and $20 \%$ for models including Staph. aureus and NAS, respectively. This significant herd variance in the impact of infections on SCC indicates that unidentified herd management factors play an important role. This underlines the importance of confirming the diagnosis with bacteriological sampling, and also indicates that the optimal threshold is farm-dependent.

The distribution of SCC was described under Norwegian management conditions. Because variation in SCC can vary between management systems and breeds, one 


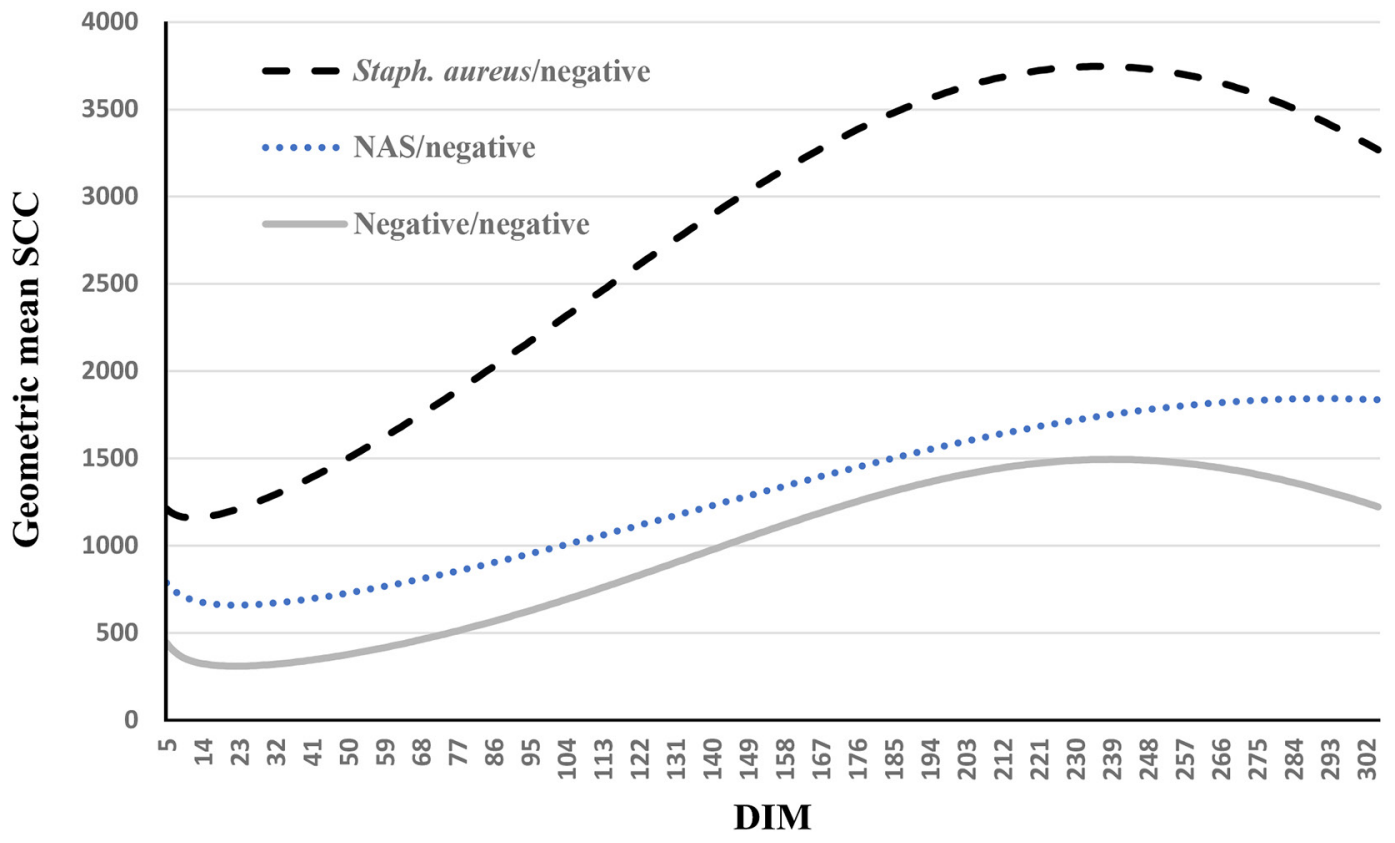

Figure 6. Geometric mean SCC $(\times 1,000$ cells $/ \mathrm{mL})$ in goat milk recordings (all parities, $\mathrm{n}=9,372)$ according to DIM and infection status in the udder halves: negative/negative $=$ culture negative in both halves; NAS/negative $=$ NAS in one half, culture negative in the contralateral half; Staph. aureus/negative = Staphylococcus aureus in one half, culture negative in the contralateral half.

should be careful in extrapolating the result to other countries.

\section{CONCLUSIONS}

The median SCC in the goat milk recordings in the Norwegian Goat Recording System was 440,000 cells/mL, and the modes were 70,000 cells $/ \mathrm{mL}$ and 110,000 cells $/ \mathrm{mL}$ from fourth parity and higher. The study describes SCC at different parities and stages of lactation under Norwegian management conditions and could thus serve as a guideline for interpretation of SCC. The substantial variation in SCC associated with physiological factors indicates that threshold values for distinguishing infected from noninfected goats must be adjusted according to parity, stage of lactation, and season. Using such dynamic thresholds, SCC may become a valuable indicator of subclinical mastitis in dairy goats.

\section{ACKNOWLEDGMENTS}

This work was a part of the project "High somatic cell numbers in goat milk - Influence on product quality," which received financial contribution from the Norwegian Foundation for Research Levy on Agricultural Products (Oslo, Norway) and the Norwegian Agricultural Agreement Research Fund (grant number 320834, Oslo, Norway). The work was also supported by the Norwegian Research Council (grant number 288917, Oslo, Norway) and TINE SA (Oslo, Norway). The authors have not stated any conflicts of interest.

\section{REFERENCES}

Ådnøy, T. 2014. The dairy goat industry in Norway: Challenges in a historical perspective. Small Rumin. Res. 122:4-9. https://doi .org/10.1016/j.smallrumres.2014.07.011.

Bagnicka, E., A. Winnicka, A. Jóźwik, M. Rzewuska, N. Strzałkowska, E. Kościuczuk, B. Prusak, J. Kaba, J. Horbańczuk, and J. Krzyżewski. 2011. Relationship between somatic cell count and bacterial pathogens in goat milk. Small Rumin. Res. 100:72-77. https://doi.org/10.1016/j.smallrumres.2011.04.014.

Bergonier, D., R. de Crémoux, R. Rupp, G. Lagriffoul, and X. Berthelot. 2003. Mastitis of dairy small ruminants. Vet. Res. 34:689-716. https://doi.org/10.1051/vetres:2003030.

Bernier Gosselin, V. B., S. Dufour, and J. R. Middleton. 2020. Association between species-specific staphylococcal intramammary infections and milk somatic cell score over time in dairy goats. Prev. Vet. Med. 174:104815. https://doi.org/10.1016/j.prevetmed .2019 .104815 .

Contreras, A., J. Corrales, D. Sierra, and J. Marco. 1995. Prevalence and aetiology of non-clinical intramammary infection in MurcianoGranadina goats. Small Rumin. Res. 17:71-78. https://doi.org/10 .1016/0921-4488(95)00651-Z

de Haas, Y., R. Veerkamp, H. Barkema, Y. Gröhn, and Y. Schukken. 2004. Associations between pathogen-specific cases of clinical mastitis and somatic cell count patterns. J. Dairy Sci. 87:95-105. https://doi.org/10.3168/jds.S0022-0302(04)73146-X.

Deinhofer, M., and A. Pernthaner. 1995. Staphylococcus spp. as mastitis-related pathogens in goat milk. Vet. Microbiol. 43:161-166. https://doi.org/10.1016/0378-1135(95)92532-G.

Devold, T. G., R. Nordbø, T. Langsrud, C. Svenning, M. J. Brovold, E. S. Sørensen, B. Christensen, T. Ådnøy, and G. E. Vegarud. 2011. Extreme frequencies of the $\alpha_{\mathrm{S}_{1}}$-casein "null" variant in milk from 
Norwegian dairy goats - Implications for milk composition, micellar size and renneting properties. Dairy Sci. Technol. 91:39-51.

Halasa, T., K. Huijps, O. Østerås, and H. Hogeveen. 2007. Economic effects of bovine mastitis and mastitis management: A review. Vet. Q. 29:18-31. https://doi.org/10.1080/01652176.2007.9695224.

Hogan, J. S., R. N. Gonzalez, R. J. Harmon, S. C. Nickerson, S. P. Oliver, J. W. Pankey, and K. L. Smith. 1999. Laboratory Handbook on Bovine Mastitis. Rev. ed. National Mastitis Council.

IDF. 1997. Recommendations for presentation of mastitis-related data. Bull. IDF 321.

Jiménez-Granado, R., M. Sánchez-Rodríguez, C. Arce, and V. Rodríguez-Estévez. 2014. Factors affecting somatic cell count in dairy goats: A review. Span. J. Agric. Res. 12:133-150. https://doi.org/ 10.5424/sjar/2014121-3803.

Koop, G., S. De Vliegher, A. De Visscher, K. Supré, F. Haesebrouck, M. Nielen, and T. Van Werven. 2012. Differences between coagulase-negative Staphylococcus species in persistence and in effect on somatic cell count and milk yield in dairy goats. J. Dairy Sci. 95:5075-5084. https://doi.org/10.3168/jds.2012-5615.

Koop, G., T. van Werven, N. Toft, and M. Nielen. 2011. Estimating test characteristics of somatic cell count to detect Staphylococcus aureus-infected dairy goats using latent class analysis. J. Dairy Sci. 94:2902-2911. https://doi.org/10.3168/jds.2010-3929.

Leitner, G., U. Merin, Y. Lavi, A. Egber, and N. Silanikove. 2007. Aetiology of intramammary infection and its effect on milk composition in goat flocks. J. Dairy Res. 74:186-193. https://doi.org/ $10.1017 /$ S0022029906002299.

Leitner, G., U. Merin, N. Silanikove, E. Ezra, M. Chaffer, N. Gollop, M. Winkler, A. Glickman, and A. Saran. 2004. Effect of subclinical intramammary infection on somatic cell counts, NAGase activity and gross composition of goats' milk. J. Dairy Res. 71:311-315. https://doi.org/10.1017/S0022029904000305.

Luengo, C., A. Sánchez, J. C. Corrales, C. Fernández, and A. Contreras. 2004. Influence of intramammary infection and non-infection factors on somatic cell counts in dairy goats. J. Dairy Res. 71:169174. https://doi.org/10.1017/S0022029904000019.

Moroni, P., G. Pisoni, G. Ruffo, and P. Boettcher. 2005. Risk factors for intramammary infections and relationship with somatic-cell counts in Italian dairy goats. Prev. Vet. Med. 69:163-173. https:/ /doi.org/10.1016/j.prevetmed.2004.10.013.

Nagel-Alne, G. E., L. J. Asheim, J. B. Hardaker, L. Sølverød, D. Lindheim, and P. S. Valle. 2014. The Norwegian Healthier Goats programme - A financial cost-benefit analysis. Prev. Vet. Med. 114:96-105. https://doi.org/10.1016/j.prevetmed.2014.02.002.
Paape, M., B. Poutrel, A. Contreras, J. C. Marco, and A. Capuco. 2001. Milk somatic cells and lactation in small ruminants. J. Dairy Sci. 84:E237-E244. https://doi.org/10.3168/jds.S0022 -0302(01)70223-8.

Persson, Y., and I. Olofsson. 2011. Direct and indirect measurement of somatic cell count as indicator of intramammary infection in dairy goats. Acta Vet. Scand. 53:15. https://doi.org/10.1186/1751 $-0147-53-15$

Reksen, O., L. Sølverød, and O. Østerås. 2008. Relationships between milk culture results and composite milk somatic cell counts in Norwegian dairy cattle. J. Dairy Sci. 91:3102-3113. https://doi.org/ $10.3168 /$ jds. $2008-1006$.

Skeie, S., R. A. Inglingstad, L. Brunborg, and M. Eknæs. 2014. The influence of the deletion in exon 12 of the gene encoding $\alpha_{\mathrm{S}^{-}}$ casein (CSN1S1) in the milk of the Norwegian dairy goat breed on milk coagulation properties and cheese quality. Small Rumin. Res. 122:50-58. https://doi.org/10.1016/j.smallrumres.2014.07.019.

Taponen, S., E. Liski, A.-M. Heikkilä, and S. Pyörälä. 2017. Factors associated with intramammary infection in dairy cows caused by coagulase-negative staphylococci, Staphylococcus aureus, Streptococcus uberis, Streptococcus dysgalactiae, Corynebacterium bovis, or Escherichia coli. J. Dairy Sci. 100:493-503. https://doi.org/10 .3168/jds.2016-11465.

TINE. 2020. Statistikk fra Kukontrollen og Geitekontrollen, [Statistics from the Norwegian Dairy Herd Recording System and the Norwegian Goat Recording system, yearly report 2020]. Accessed Jul. 26, 2021. https://medlem.tine.no/fag-og -forskning/statistikk-2020-for-kukontrollen-og-geitekontrollen/ _attachment/inline/59a4610f-2d7e-4b6f-a37a-7f43c9977306 53e8e6153c6fa6348276b5cc0bc8e9b3a58d6079/Statistikksamling $\% 20$ husdyrkontrollen\%202020.pdf.

White, E., and L. Hinckley. 1999. Prevalence of mastitis pathogens in goat milk. Small Rumin. Res. 33:117-121. https://doi.org/10 .1016/S0921-4488(99)00013-9.

\section{ORCIDS}

M. Smistad ๑ https://orcid.org/0000-0002-9282-3594

R. A. Inglingstad (ํ) https://orcid.org/0000-0001-6413-7557

O. Østerås (ํ) https://orcid.org/0000-0002-1292-592X 